\title{
Towards a Praxis of Educational Solidarity
}

\author{
Monisha Bajaj and David Tow (University of San Francisco)
}

\begin{abstract}
:
In this article, the authors locate examples of solidarity in the structures and practices of two educational institutions in Northern California. Applying a taxonomy of solidarity drawn from Gaztambide-Fernández (2012) to two schools' responses to Covid19, the authors delineate serendipitous acts of solidarity from intentional and deliberate solidarity praxes that have been deepened during the pandemic. This article sheds light on possibilities to reimagine educational solidarity post-Covid in order to further the process of humanizing education and advancing greater equity and justice.
\end{abstract}

Keywords:

education; empathy; immigration; solidarity; student agency

Since World War II, with the decolonization of dozens of nation-states and the rise of global frameworks for advancing the right to education, more children have entered school than ever before in human history. Eighty percent of children worldwide currently attend school according to recent data (UNESCO, 2018). While what happens in school may vary in quality, equity and respect for basic dignity, the fact that the school as an institution plays such a monumental role in children's and families' lives is undeniable. In this article, we examine the role of public schools in the Northern California Bay Area as sites for structures and practices of solidarity prior to and during the Covid-19 pandemic and resultant socio-economic crises; we draw from the framework provided by educational scholar Ruben GaztambideFernández for a "pedagogy of solidarity committed to decolonization and anti-oppressive praxis" (GaztambideFernández, 2012, p. 41, 43).

We argue that schooling occupies a unique position in the United States (U.S.) as the only economic and social right universally guaranteed in contrast to the right to food, housing, and healthcare which are not universally accessible to residents in the U.S., and unlikely to be given current political arrangements. As such, some schools have deliberately attempted to forge solidarity-based structures and practices to meet the needs and realities of the most marginalized communities in addition to offering academic training. We first offer the example of Canal High School (Canal), ${ }^{1}$ not explicitly engaged in praxes of solidarity prior to Covid-19, but that through the crises being faced by students, has increasingly engaged in mutual aid and direct service provision, resulting in greater horizontality and support for marginalized students. ${ }^{2} \mathrm{We}$ then provide the example of Rudsdale Newcomer Academy (RNA), a high school that was deliberately established to serve high-poverty immigrant communities and has expanded its relational praxes of solidarity during the Covid-19 pandemic. Through the examination of these two public high schools, we argue that educators and schools must galvanize the resources available to them and exert their agency to deepen their structures and practices of solidarity even after the Covid-19 pandemic in order to reimagine education and its purposes both in the U.S. and globally.

\section{Pedagogies of Solidarity}

Rather than subscribing to ambiguous conceptions of solidarity that favor consensus building at the cost of obscuring discrete identities of diverse possibility, perpetuating neoliberal forms of organizing, and reinscribing settler colonial logics, we aim to advance a notion of solidarity that challenges inequity, injustice and colonialism. Our notion is more in line with Zembylas' sense of solidarity as a radical "intensification" grounded in "empathy, a community of engaged citizens and the constant interrogation of various modes of action and engagement for their effectiveness to fight injustice and subordination" (Zembylas, 2013, p. 516). As such, solidarity is not merely a vague notion of collaborative labor, but part of a daily practice with liberatory and emancipatory objectives grounded in a concrete sense of justice. Solidarity can describe actions taken in the advancement of justice or those collaborative efforts that inadvertently result in interrogation, engagement, or action. Camangian and Cariaga (2021), meanwhile, wisely observe that, 
Solidarity requires that people are able to do the difficult work of relinquishing various privileges so that those who are participating in the community space can unpack tensions, learn from dialogue, and reimagine a future that is inclusive of poor and working-class communities; gender fluid, queer, and trans people; and differently abled, atypically bodied, and deaf communities of color and allies within and across varying ethnic and social groups (Camangian \& Cariaga, 2021, p. 11).

This kind of action, requiring direct aid, space for participation, and the appreciation of difference while eliminating the unequal privileges they convey, gestures toward solidarity as a multivalent and multidimensional set of community behaviors, rather than a single performative action. With the dramatic unsettling of the normal conduct of compulsory education under the conditions created by Covid-19, we want to locate these efforts specifically in the structures and practices of education.

Drawing on the work of Gaztambide-Fernández, we also want to emphasize the three different facets that make up solidarity, especially within educational contexts: (1) “a relationship among individuals or groups", (2) "a sense of duty regarding what is just or equitable", and (3) the implicit golden rule, a "disposition to treat others as one would like to be treated" (Gaztambide-Fernández, 2012, p. 50). For Gaztambide-Fernández, as for us, these three desiderata allow opportunities for decolonial and anti-oppressive educational practice. Moreover, it permits us to evaluate steps taken during Covid-19 using a clear rubric: to what extent do they build or build upon relationships, what and whose sense of duty and equity is being enacted, and how closely are the actions bound by a doctrine of reciprocity?

Having established a working definition of solidarity as we see it in these contexts and suggested criteria by which we analyze the steps towards it, we would like to now briefly sketch a taxonomy of solidarity, also drawn from Gaztambide-Fernández (2012, pp. 51-57). The three varieties of solidarity at work in these examples are relational solidarity, transitive solidarity, and creative solidarity. Relational solidarity is an intersubjective endeavor, emphasizing how individuals are made and remade through relations with others. Transitive solidarity, meanwhile, involves going beyond identification or empathy, instead favoring entering into the circumstances with those whom solidarity is being built. Instead of collaboration from without, transitive solidarity requires transformation from within. Finally, creative solidarity is a form grounded in culture as not just a constituent part of identity or static category but as a site of decolonial and anti-oppressive action. Taken together, these categories allow solidarity to appear and exist in many places simultaneously, while appearing and functioning differently each time. In this way, solidarity is a spirit of action, an objective-driven praxis, and an ethic of relation.

\section{Serendipitous Acts of Solidarity}

There is little novelty in observing that public schools do not fully meet the needs of historically marginalized and multiply-marginalized students and their communities in the United States. Indeed, this underservice seems to be among the chief underlying principles driving public schooling, along with neoliberalism, racial capitalism, settler colonialism, and the social reproduction of U.S. imperial thought (hooks, 1994, 2003; Leonardo, 2009; paperson, 2017; Tibbitts, 2017). This denial of resources, support, content, and a pedagogy that values these communities' experiences and perspectives, what Linda Darling-Hammond (2001) calls the "rationing of opportunity," manifests through both teacher practices and the inequitable structural allocation. However, among the unmitigated tragedy of the Covid-19 pandemic and the accompanying (and preventable) economic catastrophe, the reproduction and immediate effects of rationing have become interrupted. With the closure or near-closure of many physical school sites and the decentralization of school services, the support, operation, and daily task of schools has shifted. Within this shift, institutions that resist critique invited practical interruptions to dominant harmful ideologies without the accompanying vocabulary. Put simply, while they may not have been actively promoting these praxes of solidarity, they have accidentally stumbled towards solidarity and horizontality.

Canal High School ("Canal") is a typical California public high school. It is a medium-sized high school north of the Golden Gate Bridge in the San Francisco Bay Area. Canal is a handy example of the responses of average suburban and urban-adjacent public high schools for two primary reasons: (1) it is within the middle half of public high schools in terms of English language arts and mathematics scores (according to the flawed metrics used to calculate these categories) (EdData, 2021; National Center for Educational Statistics, 2020; Public School Review, 2021); and (2) its student body represents many suburban high schools in California with a student population that is $8 \%$ Asian, 3\% Black, $1 \%$ Indigenous American, 44\% Latino/a/x, and 43\% White. As such, looking at how accidental pushes towards solidarity and horizontality have appeared here suggest steps that have been or may be taken elsewhere as well. These pushes are best sorted into two general categories.

The first category includes initiatives taken by administration and district staff in response to the pandemic that resulted in solidarity with students. Principally, school leaders reevaluated the services the school provided and the resources to support them not just to students, but to the community as a whole and then, in response to that, rebalanced them. Very quickly, schools became hubs for technology for students and their parents, as well as food distribution sites for meals at-will. These steps have been well-publicized at schools across the country. Less discussed is the subsequent reinvention of the school as a starting point 
for social services, assistance, and material aid more generally. In this way, schools like Canal have become points of contact like $311,{ }^{3}$ though more defined by and connected to the communities they serve. Although, also like 311, these efforts are hamstrung by little sustained investment in social safety nets and infinitely more need than available supply, there is great promise here for a vision of schools as more community-embedded bodies.

Another early step the school took was opening up what were informally called "learning pods" - small groups of students who were unable to meaningfully participate in school without access to the actual school site. Among the students who participate in the learning pods are those without access to consistent housing and food, students without permanent addresses, students with special needs that cannot be met by schools remotely, immigrant-origin students and English language learners who require sustained access to teachers and supports, and students with other material or emotional needs. The reports from both students and teachers have been nearly universally positive, with comments that they both improved educational outcomes and psychological stability - both impressive accomplishments these days. Despite these bright spots, the learning pods remain an under-utilized opportunity, both because of valid concerns about transmission and because of poor evangelism and marketing. Many students who would benefit from these pods and meet the target demographics are still, nearly 9 months in at the time of this writing, unaware of their existence. Another major step has been a shift in the traditional power hierarchy. Before the pandemic, and even during the early days, the school and its district embodied the typical corporate hierarchy of public (and private) institutions. However, as the pandemic and remote learning have persisted, the sense of duty, which way that duty flowed, and to whom things were meant to serve reversed course. Generally, this resulted in emphasizing the centrality of students in school policy. Of course, students were always the constituents of school, but now they are reframed as an audience that must be reached. In this way, students' needs are the first consideration, with those considerations further from the point of contact between teachers and students appearing secondarily. Technology has inadvertently given students more power in the school dynamic. Students now have the power to determine their own context and location from which to access schooling, can control their audio and visual engagement with the class, or engage only via text, chat, or other inputs. This sea change is only now being considered, but we hope the student agency that has resulted persists. The process of school is decentralized and defined by negotiation, communication, and reasonability, which is a much more humanizing process. Going forward, the school could preserve this shift by codifying it in the management structure, perhaps by investing student government or councils with the power to shape, advance, and veto policy.
The second category describes some steps taken by teachers or by teachers with students that result in solidarity. Principally, the major shift has been to treating the school day as a resource and space for students, rather than a rigid schedule with metrics determining whether that time has been more or less effective. One factor in this shift has been through the conscious rollout of an "advisory" model, where a one-day-a-week course focusing on students' wellbeing aims to sustain their sense of community and foster collaborative and collective support. Another factor has been the explicit expansion of teacher office hours - with office hours more a clearly named space for students and teachers to work together rather than the unnamed "drop in" hours from in-person learning. This reveals a larger movement away from the control and management of student time and towards emphasizing students' as co-equal participants in the process of schooling, allowing them the responsibility to allocate their time as they best see fit. Overall, the school's teachers have emphasized student agency and autonomy as desired outcomes, hoping students will exit the pandemic feeling empowered and with the language and self-awareness to unpack the trauma collectively.

Similarly, teachers have noted the transition away from deficit language, speaking about students as if they are below a standard or lesser than another group of students, and the unconscious but widespread use of trauma-informed language, aiming to identify and understand the impacts of poverty, racism, violence, and other social harms. Partially, this shift is explained through the plain way in which the collective and individual trauma of Covid-19 is welcome in regular discourse. ${ }^{4}$ It is also explained via a need articulated by teachers to retain and reinforce relationships with students, and trauma-informed practices offer an emotionally direct idiom for students and teachers to converse in even over distances. Meanwhile, the structural changes to the school day and the distributed nature of learning made deficit language neither descriptively helpful nor practically useful, since normative conceptions of pacing and proficiency were mostly thrown out the window. Even more promising is how these trauma-informed practices are beginning to proliferate into classrooms and conversations with and between students, though teachers must be wary to not retraumatize or further alienate students.

Another step has been the push towards humanizing (and, arguably, humanistic) grading, emphasizing student growth and recognizing the impact context and structures play in student ability to participate in school. Although initiated as a top-down decision, many of the teachers at Canal have leaned into the humane qualities of humanistic grading, and it has spread from a mere evaluative model to a pedagogical approach in many classrooms. ${ }^{5}$ Along with this change in grading has been an upstream revision in the content of classes and the manner of assessment. As with grading, this curricular change resulted from the needs and limits of remote learning, but many of the philosophical discoveries, 
sometimes radical ones, have persisted, especially in the humanities at Canal, where subjects like critical pedagogy and decoloniality have gone from informing some teachers' theories of education to manifesting within the curriculum itself. $^{6}$

These steps taken by both administrators and teachers, have served to humanize an institution that, like most public bodies, is resistant to structural change, despite the drive and inclination of those who labor within them. However, in the decentralized nature of public education under Covid-19, individual dedications to duty and equity enable first steps towards solidarity and potential future reciprocity.

\section{Deepening Praxes of Solidarity During Crisis}

A "pedagogy of solidarity committed to decolonization" necessitates the uncovering of colonial logics that undergird present realities (Gaztambide-Fernández, 2012, p. 41). The legacy of neo-imperialist and Cold-War interventionist U.S. foreign policy towards Central America in decades past - for example, the United States' support for the military regime in El Salvador from 1979 - 1992 that massacred 75,000 citizens - has contributed to the destabilizing of the region. Current violence and insecurity fuel the widespread desire for out-migration from the Central American nations of El Salvador, Honduras and Guatemala. In 2009, approximately 3,000 unaccompanied minors from Central America were apprehended at the U.S. border; by 2014, that number increased to approximately 55,000 and has fluctuated since (most recent data shows an estimated 60,000 unaccompanied minors from Central America arriving to the U.S. in 2019). ${ }^{7}$ Unaccompanied minors are youth under the age of 18 , usually boys, who migrate without immediate family. After the apprehension of these minors, immigration laws (prior to and after their widespread violation during the Trump regime) allow them to be placed with a relative while their asylum cases proceed.

In Oakland, California - home to a large Central American immigrant community - the school district has seen a large influx of unaccompanied minors entering their schools over the past decade; according to a local news agency "Nearly one in five high school students in the Oakland Unified School District is new to the country" (KQED, 2020). While certain programs for "newcomer" students that previously existed were able to integrate some of these students, the school district realized that it was difficult to meet the needs of students most at risk of dropping out, namely, students who had to work to support themselves and their families (and to pay off debts related to coming to the U.S.).

Given the very low levels of school completion for unaccompanied minors in Oakland, a unique continuation program, ${ }^{8}$ Rudsdale Newcomer Academy (RNA), was established in 2017 with the express purpose of providing a flexible and tailored approach to meeting the needs of newcomer youth (who may or may not be unaccompanied minors, though the majority are), many of whom had substantial work and other commitments. The school serves approximately 200 students all of whom have arrived in the U.S. within the past three years. The structures and practices of the school that were designed deliberately in solidarity with the needs of these students and their families included:

(1) A later start time and shorter school day than most schools (9:30am to $2: 30 \mathrm{pm})$ since many students work after-school and late into the night as dishwashers in restaurants or at other low-wage jobs; (2) Six-week credit bearing courses that allow students to take leaves of absence if required and be able to integrate back into their academic program; (3) Year-round admission that can accommodate students whenever they arrive throughout the school year with an orientation for new students held every 6 weeks; (4) A focus on socioemotional learning (SEL), restorative justice (RJ), and trauma-informed approaches to address migrant students' distinct realities; and (5) Workshops every month to assist students and the families they are living with to find out about government programs, such as Medi-Cal (free healthcare for California residents living in poverty). (6) Partnerships with legal aid organizations where lawyers come to the school campus regularly to help students with their immigration cases and court hearings.

All the students at RNA qualify for free lunch (which is one measure utilized in the U.S. to determine levels of student poverty), and, as such, the school serves lunch to students daily. The head of Rudsdale Newcomer Academy Emma Batten-Bowman sums up the school's approach:

We have some kids who have seen gang members murdering people in front of their face in their home country. Then, if they can escape that violence, they have this horrible journey across Mexico where they might be essentially treated like dogs. Then they get to the United States and they usually get locked in a cage. Kids tell me, "We only got one meal a day and it was a cup of noodles." Kids might be there for months and months. Then they get to Oakland where, if they are lucky, they are living with extended family. We see a lot of sexual, emotional and physical abuse happening. We just had a student attacked and stabbed by his co-worker. So when they come to school and they're a little unfocused or they miss three days, there has to be more compassion for them. We don't need to coddle them, but we do need to be really understanding. One of the things that we've been working on now is teaching our students professionalism. "We know you're going to miss a lot of school, so when you have to miss school, you have to let us know. Text your teacher, write an email or call the main office." That level of compassion and really getting to know students 
through strong relationships is the basis of RJ and SEL.

(E. Batten-Bowman, interview, January 2020)

Trauma-informed approaches offer a humanizing way for educators and school staff to engage with students without resorting to narratives of "pity" that posit the teacher as the savior of children from marginalized communities (Cammarota, 2011). By centering the needs of the student population, Rudsdale Newcomer Academy focuses on flexibility and building close-knit relationships with students, as other studies have discussed the value of (Bajaj, 2009; Hantzopoulos, 2016), so that when emergencies or crises arise, the school can respond meaningfully to help students.

Covid-19 presented such a crisis, with schools being shut down, limiting the support students at Rudsdale Newcomer Academy previously received in-person, and causing much financial hardship to students given the closure of restaurants and other businesses where they previously worked. Teachers and volunteers have sought to secure food from the school district and local agencies, and deliver it to students and their families given that many do not have cars or information about how to access such services. Teachers have also helped students and their family members file paperwork for state benefits they may not be aware of. Through grants, crowdfunding efforts, and mutual aid, teachers and administrators have also been able to get internet hot spots to families; Chromebooks for completing schoolwork since $80 \%$ of the students had no way to access remote schooling otherwise; and direct financial assistance with rent, food and other necessities. ${ }^{9}$ The school has given out an average of $\$ 10,000$ per month since April 2020 in direct aid to students and their families (E. Batten-Bowman, personal communication, February 2021). Such efforts demonstrate a duty and ethic of care, with the extension of close relationships and reciprocity fostered previously in the school environment extending to students who are now learning from home. While school buildings have yet to reopen at the time of this writing after nearly a year of being closed due to Covid-19, many students may not return with the demands of survival taking precedence over their educational pursuits. Certain employment, such as in the construction industry as day laborers, that newcomer students may find themselves relegated to with the closure or downsizing of restaurants where many previously worked, is incompatible with attending school even with RNA's more flexible schedule. Solidarity-based structures and praxes prior to and during Covid-19 have positioned the school better than many others to serve the material needs of their students; however, without a robust social safety net beyond that already offered by the school for students and their families, the impact of solidarity on long-term educational persistence may be constrained.

\section{Concluding Thoughts}

The pedagogies and praxes of two Northern California Bay Area schools and their responses during the Covid-19 pandemic demonstrate how educational institutions can act in solidarity to mitigate deep inequalities that adversely impact their students and families. While public schooling has long tended to reproduce social, economic, and racial inequalities (Bourdieu \& Passeron, 1977), schools are also sites of agency, resistance, contestation, and community (Bajaj, 2009, 2018; Carnoy \& Levin, 1985; Freire, 1970; Hantzopoulos, 2016). Furthermore, the disruption of the pandemic has introduced changes that have, regardless of intent, offered beneficial side effects for those whose voices are frequently not centered in education. In this essay, we have sketched a taxonomy of solidarity and applied it to examine the innovative structures and practices occurring within Canal High School and Rudsdale Newcomer Academy. Through the lenses provided by GaztambideFernández, we identified praxes of relational, transitive and creative solidarity occurring prior to and during Covid-19 at each school site in different ways. For example, the existing deep relational solidarity praxes at Rudsdale Newcomer Academy extended into material aid for students and families generated through the leveraging of community support. At Canal, educators enacted (and continue to enact) transitive solidarity by developing deep empathy for the whole lives of students, and generating new ideas (creative solidarity) that may over time question and transform the oppressive hierarchies of the educational system.

Educators and staff of the two public high schools in the Northern California Bay Area have sought to defy their reproductive institutional logics and humanize their praxes to meet students' survival, well-being, and academic needs. Whether new structures or praxes of educational solidarity have emerged during the pandemic or existing ones have been extended, the process and outcomes of humanizing education for students and families reposit the role of the school as a central resource and hub in the life of the community. In this essay, while we describe practices that have built upon relationships and senses of duty, they do not yet manifest a doctrine of reciprocity. However, as schools reopen for in-person learning and the collective efforts of schools can be pooled - not just virtually but physically as well - we anticipate opportunities to articulate an explicit doctrine of reciprocity in each school site. Hopefully, these steps toward an anti-oppressive and decolonial praxis will help students, schools, and teachers ensure that when schools return to some sort of normal, it will be into something better. 


\section{References}

Bajaj, M. (2009). Why context matters: The material conditions of caring in Zambia. International Journal of Qualitative Studies in Education, 22(4), 379-398.

Bajaj, M. (2018). Conceptualizing transformative agency in education for peace, human rights \& social justice. International Journal of Human Rights Education 2(1), 1-22.

Bourdieu, P., \& Passeron, J. (1977). Reproduction in education, society and culture. Sage Publications.

Camangian, P., \& Cariaga, S. (2021). Social and emotional learning is hegemonic miseducation: students deserve humanization instead. Race Ethnicity and Education. https://doi.org/10.1080/13613324.2020.1798374

Cammarota, J. (2011). Blindsided by the avatar: White saviors and allies out of Hollywood. Education, Review of Education, Pedagogy, and Cultural Studies, 33(3), 242-259. https://doi.org/10.1080/10714413.2011.585287

Carnoy, M. \& Levin, H. (1985). Schooling and work in the democratic state. Stanford University Press.

Darling-Hammond, L. (2001). Inequality in teaching and schooling: How opportunity is rationed to students of color in America. National Center for Biotechnology Information. https://www.ncbi.nlm.nih.gov/books/NBK223640/.

Ed-Data. (n.d.). Ed-Data Education Data Partnership - School Summary. Retrieved April 15, 2021, from https://www.eddata.org/school

Edwards-Groves, C., Brennan Kemmis, R., Hardy, I., \& Ponte, P. (2010). Relational architectures: recovering solidarity and agency as living practices in education. Pedagogy, Culture \& Society, 18(1), 43-54. https://doi.org/10.1080/14681360903556814

Freire, P. (1970). Pedagogy of the oppressed. Continuum.

Gaztambide-Fernández, R. A. (2012). Decolonization and the pedagogy of solidarity. Decolonization: Indigeneity, Education \& Society, 1(1), 41-67.

Hantzopoulos, M. (2016). Restoring dignity in public schools: Human rights education in action. Teachers College Press.

hooks, b. (1993). Teaching to transgress. Routledge.

hooks, b. (2003). Teaching community: A Pedagogy of Hope. Routledge.

Juris, J. (2008). Spaces of intentionality: race, class, and horizontality at the United States Social Forum. Mobilization: An International Quarterly, 13(4), 353-371.

Leonardo, Z. (2009). Race, whiteness, and education. Routledge.

National Center for Education Statistics. (n.d.). Search for schools and colleges. Retrieved April 15, 2021, from https://nces.ed.gov/globallocator

paperson, 1. (2017). A third university is possible. University of Minnesota Press.

Public School Review. (n.d.). Public schools by distance. Retrieved April 15, 2021, from https://www.publicschoolreview.com

Rancaño, V. (2020, May 14). Jobs, laptops, food: How Rudsdale High teachers are helping newcomer students during COVID-19. KQED. https://www.kqed.org/news/11817366/jobs-laptops-food-how-rudsdale-high-teachers-arehelping-newcomer-students-during-covid-19

Tibbitts, F. L. (2017). Revisiting 'Emerging models of human rights education'. International Journal of Human Rights Education, 1(1). https://repository.usfca.edu/ijhre/vol1/iss 1/2

UNESCO. (2018). Out-of-school children and youth. United Nations Educational, Scientific and Cultural Organization. http://uis.unesco.org/en/topic/out-school-children-and-youth.

Zembylas, M. (2013). The "crisis of pity" and the radicalization of solidarity: Toward critical pedagogies of compassion. Educational Studies 49(6), 504-521. https://doi.org/10.1080/00131946.2013.844148 


\section{Recommended Citation}

Bajaj, M., \& Tow, D. (2021). Towards a praxis of educational solidarity. On Education. Journal for Research and Debate, 4(10). https://doi.org/10.17899/on_ed.2021.10.6

\section{About the Authors}

Monisha Bajaj is Professor of International and Multicultural Education at the University of San Francisco, and Visiting Professor at Nelson Mandela University, South Africa.

David Tow is an English and social science teacher in the San Francisco Bay Area, and a doctoral student of International and Multicultural Education at the University of San Francisco.

\footnotetext{
${ }^{1}$ A pseudonym.

${ }^{2}$ As noted by Juris (2008), "Popularized by grassroots autonomous movements in Argentina, the term horizontality refers to an increasingly widespread mode of political organizing characterized by nonhierarchical relations, decentralized coordination, direct democracy, and the striving for consensus" (Juris, 2008, p. 354).

${ }^{3}$ In the United States and parts of Canada, 311 is a special-purpose telephone number connecting callers to non-emergency public services ranging from complaints about potholes to connecting unhoused residents with assistance.

${ }^{4}$ Early on, administrators at Canal foregrounded teacher emotional well-being and overtly de-emphasized rigid fidelity to testing, which increased as state testing was cancelled for the year. This discursive mode cascades out to classrooms too, de-emphasizing preexisting pacing plans and inflexible evaluative criteria, instead favoring student-centered and subjective learning outcomes, emotional well-being and traumainformed language, and generally centering students' personal well-being over strictly academic well-being.

${ }^{5}$ Following this trend, some of the high-stakes tests that students have been subject to are on hold, like college entrance or proficiency exams, or have been reduced, like Advanced Placement (AP) exams. Although last year, state-mandated standardized examinations were universally waived, the Biden administration has reversed that decision, citing the need for performance metrics on state education dashboards.

${ }^{6}$ In response to student input, Canal revised their college-preparatory Junior (Grade 11) and Senior (Grade 12) English classes, which resulted in a year-long Social Justice and Identity course that explores these topics and others, which has also led to their introduction elsewhere in the humanities. In the school's Honors Philosophy course, students participate in learning that aims to emulate critical pedagogy.

${ }^{7}$ Data from: https://fas.org/sgp/crs/homesec/R43599.pdf

${ }^{8}$ Continuation schools are alternative schools that provide students who are at high risk of dropping out the opportunity to complete a high school diploma using more flexible models and approaches than are usually offered in a traditional secondary school.

${ }^{9}$ For more on these community efforts, please see: https://www.kqed.org/news/11817366/jobs-laptops-food-how-rudsdale-high-teachers-arehelping-newcomer-students-during-covid-19
} 